\title{
Inflation and Public Debt Reversals in the G7 Countries
}

\author{
Bernardin Akitoby \\ International Monetary Fund, United States of America \\ bakitoby@imf.org \\ Ariel Binder \\ University of Michigan, United States of America \\ ajbinder@umich.edu \\ Takuji Komatsuzaki ${ }^{1}$ \\ International Monetary Fund, United States of America \\ tkomatsuzaki@imf.org
}

\begin{abstract}
This paper investigates the impact of low or high inflation on the public debt-to-GDP ratio in the G-7 countries. Our simulations suggest that if inflation were to fall to zero for five years, the average net debt-to-GDP ratio would increase by about 5 percentage points during that period. In contrast, raising inflation to 6 percent for the next five years would reduce the average net debtto-GDP ratio by about 11 percentage points under the full Fisher effect and about 14 percentage points under the partial Fisher effect. Thus higher inflation could help reduce the public debt-toGDP ratio somewhat in advanced economies. However, it could hardly solve the debt problem on its own and would raise significant challenges and risks. First of all, it may be difficult to create higher inflation, as evidenced by Japan's experience in the last few decades. In addition, an unanchoring of inflation expectations could increase long-term real interest rates, distort resource allocation, reduce economic growth, and hurt the lower-income households.
\end{abstract}

JEL classification: E31; F34; H63

Keywords: Inflation; debt crisis; G7; public debt; sovereign debt.

\section{INTRODUCTION}

The global financial crisis has led to unprecedented public debt build-ups in peacetime, thereby raising serious concerns about debt sustainability in advanced economies (Figure 1). If history is any guide, the current environment of low growth and falling inflation will compound

Corresponding author: International Monetary Fund. Tel: (202)-623-8486 Fax: (202)589-8486 E-mail: tkomatsuzaki@imf.org 
the scale of the problem. A situation of very low or even negative growth - as already experienced in the euro area - certainly makes the task of reversing high debt more difficult, as it makes debt fixed in nominal terms - more expensive in real terms. Against this background, some prominent academics have wondered whether inflation could help deal with high debt in an era of low growth. $^{2}$

Figure 1

Gross Public Debt in Advanced and G7 Economies, 1980-2017 (percent of GDP)

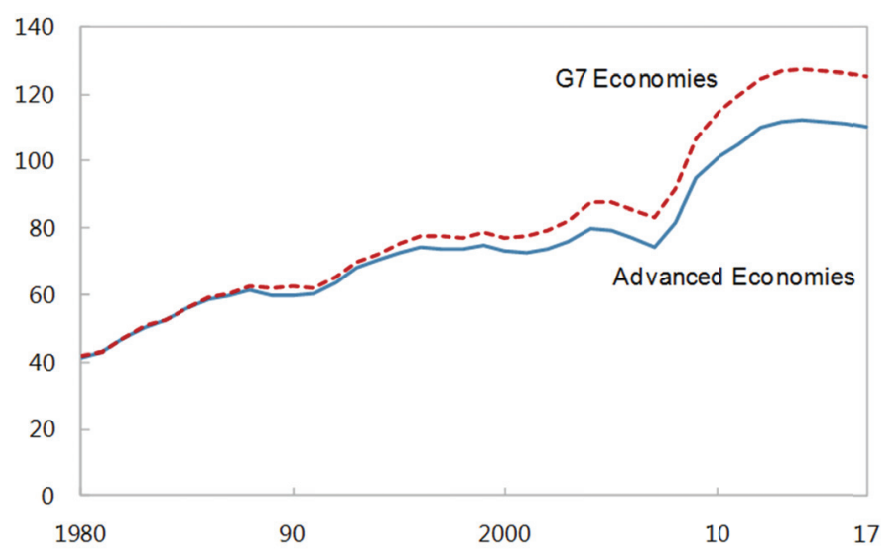

Source: Fiscal Monitor

Higher inflation could help reduce public debt through three main channels. First, governments can capture real resources through base money creation (seigniorage). Second, inflation can erode the real value of the debt. The impact of this channel will depend on the maturity structure and currency denomination of the debt, as well as on the interest rate response to higher inflation, with inflation having the largest impact on long-term, fixed-rate, and local-currency-denominated debt. Short-term debt and maturing long-term debt will need to be refinanced at higher interest rates, the floating rate debt will adjust automatically to higher rates, and the local currency value of foreign-currency-denominated debt will rise due to the currency depreciation that will accompany higher inflation. Third, inflation can affect the primary balance, including if brackets are not indexed under a progressive income tax.

The paper simulates the effect of the first two channels for G-7 countries. ${ }^{3}$ The findings show that seigniorage from higher inflation would play only a limited role in bringing down debt ratios, given the relatively low levels of base money in the G-7 countries. With regard to the impact of inflation on the real value of the debt, simulations suggest that if inflation were to fall to zero for five years, the average net debt-to-GDP ratio would increase by about 5 percentage points during that period. In contrast, raising inflation from World Economic Outlook (WEO) baseline projections to 6 percent for five years would erode the debt-to GDP ratio somewhat. Assuming that the G-7 countries have constant debt maturity structures, experience no impact of inflation on economic growth, and experience a one-for-one adjustment to inflation of nominal interest rates on newly-issued debt (full Fisher effect), the average net debt-to-GDP ratio would be reduced by about 11 percentage points during that period. Under partial Fisher effect, the net debt-to-GDP ratio reduction would be about 14 percentage points. Thus, higher inflation could have some effect on debt stocks. However, it could hardly solve the debt problem on its own and would raise significant challenges and risks.

\footnotetext{
2 See Blanchard et al. (2010), Rogoff (2008), and Ball (2012). While these authors recommend a higher inflation, they do not claim that inflation alone can solve the public debt problem.

3 A discussion of the third channel is beyond the scope of this paper.
} 
This paper is organized as follows: Section II provides a brief literature review, Section III discusses the impact of inflation on seigniorage revenue, Section IV simulates the role of inflation in eroding the real value of outstanding debt, Section V examines the robustness of the assumptions behind our simulations, and Section VI concludes.

\section{BRIEF LITERATURE REVIEW}

A recent strand of the literature on public debt reversals investigates the effect of inflation on public debt empirically. Reinhart and Sbrancia (2011) decompose the debt dynamics of selected advanced economies and emerging markets from 1945 to the present. They find that financial repression - where inflation is combined with the regulation of the financial sector - contributed to substantial debt reduction from 1945 through the 1970s in advanced economies. In contrast, using a debt dynamics equation and estimated rate of return to government bonds, Hall and Sargent (2010) find inflation's contribution to debt reduction in the U.S. from 1941 to 2009 to be modest. Similarly, applying a VAR framework to G7 countries (excluding France) over 1960-2005, Giannitsarou and Scott (2008) show that the contribution of inflation to debt movements is small. Most recently, Abbas et al. (2013) find that inflation has played a relatively minor role in a sample of 26 episodes of large debt reversals in advanced economies since the 1980s.

Another strand of the literature attempts to model the relationships between inflation, debt maturity, and public debt. Missale and Blanchard (1994) develop a model showing that when a government chooses the debt maturity it has an incentive to inflate away the debt, but faces reputational risks. In the authors' model, the longest debt maturity consistent with a credible pledge to low inflation is a decreasing function of the initial level of debt. In the model used by Aizenman and Marion (2011), the government chooses inflation while the initial debt maturity is taken as given. In calibrating their model to the U.S economy, they find that the government has an incentive to increase inflation optimally to 6 percent, resulting in a 20 percent decrease in the debt-to-GDP ratio over five years. Krause and Moyen (2011) build a standard New Keynesian DSGE model, featuring long-term debt and uncertainty regarding the targeted inflation. In this framework, raising inflation is difficult when confidence in monetary authorities remains intact. In contrast to the New Keynesian model, the literature on the Fiscal Theory of Price Level (FTPL) relaxes the assumption that the price level is determined exclusively by monetary policy while fiscal policy always adjusts to ensure debt sustainability - such as the studies by Leeper (1991), Davig and Leeper (2011), and Cochrane (2011). The FTPL model often generates high inflation depending on the coordination between fiscal and monetary policies. For instance, if fiscal policy does not ensure debt sustainability by generating sufficient primary surpluses, monetary policy should generate higher inflation to help reduce public debt - which means inflating the debt away.

Compared with the empirical literature, our paper focuses on the debt dynamics going forward. It simulates the impact of exogenous inflation shocks on public debt, thus quantifying the debt-reducing potential of higher inflation. Thus, it does not directly address the feasibility of generating inflation or the possibility of changes in monetary and fiscal policy regimes. However, we acknowledge the potential difficulty in generating high inflation, and we caution against fiscal dominance. ${ }^{4}$

\footnotetext{
4 Fiscal dominance can be defined as a situation in which monetary policy is driven by the need to ensure fiscal sustainability when fiscal policy cannot adjust.
} 


\section{SIMULATING SEIGNIORAGE FROM HIGHER INFLATION}

\subsection{Methodology}

Seigniorage represents the real revenues a government acquires by using newly issued money to buy goods and non-money assets. Using the base money stock $M_{t}$ and the price level $P_{t}$, it is defined as:

$$
\frac{\dot{M}_{t}}{P_{t}}=\mu_{t} m_{t}=\dot{m}_{t}+\pi_{t} m_{t}
$$

where $\mu_{t}=\frac{\dot{M}}{M_{t}}$, and $\dot{m}_{t}$ and $m_{t} \pi_{t}$ are growth in real money balances and inflation tax, respectively.

In princifle, a government can increase seigniorage by raising inflation for a given level of real money balances. However, if high inflation leads to a reduction in holdings of real money balances $\left(\dot{m}_{t}>0\right)$, it shrinks the effective tax base and decreases seigniorage. On the other hand, if the central bank increases the real money balance in its attempt to increase inflation, it could increase seigniorage. We assume constant real money stock, which would hold at steady state, thereby focusing on the portion of seigniorage that deals with inflation tax $\left(\pi_{t} m_{t}\right)$. We express seigniorage in terms of percentage of annual GDP and use base money as measure of money.

\subsection{Results}

Given the relatively low levels of base money in most advanced economies, seigniorage from higher inflation would play only a limited role in lowering debt ratios. Simulations suggest that one additional percentage point of inflation would raise seigniorage for the sample by about 0.12 percent of GDP annually. So, raising inflation from World Economic Outlook (WEO) baseline projections to 6 percent for five years (2013-17) would generate cumulative seigniorage revenue of about 2.5 percentage points of GDP on average (Table 1). Country-specific estimates vary from less than one percent (Canada) to about 5 percent (Japan).

Table 1

Seigniorage Gains from Inflation ${ }^{1}$

\begin{tabular}{lccc}
\hline \hline & $\begin{array}{c}2012-17 \\
\text { Inflation }^{2}\end{array}$ & $\begin{array}{c}\text { Annual Seigniorage gains, with one } \\
\text { additional percent of inflation }\end{array}$ & $\begin{array}{c}\text { Seigniorage Gains with 6 percent } \\
\text { inflation for 5 years }\end{array}$ \\
\hline Canada & 1.9 & 0.04 & 0.8 \\
Euro area & 1.6 & 0.12 & 2.7 \\
Japan & 0.3 & 0.24 & 5.3 \\
United Kingdom & 2.5 & 0.04 & 0.9 \\
United States & 1.7 & 0.17 & 3.8 \\
Average $^{4}$ & $\mathbf{1 . 6}$ & $\mathbf{0 . 1 2}$ & $\mathbf{2 . 6 9}$ \\
\hline \hline
\end{tabular}

\footnotetext{
Inflation figures are reported in percent; all other figures are in percent of GDP.

GDP deflator inflation, average over the period as projected in the WEO.

This implies an increase in inflation by 4.4 percentage points over projeted average inflation of 1.6 percent.

Simple average.

Sources: IMF, WEO, Bank of Japan, Bank of England, ECB, and Fund staff estimates.
} 


\section{EROSION OF REAL VALUE OF DEBT}

\subsection{Methodology}

\subsubsection{The debt dynamics equation}

The simulation of the "debt-erosion channel" is based on the standard debt dynamics equation. Total debt is broken down into three categories: domestic-currency-denominated, foreigncurrency-denominated, and inflation-indexed debt. Debt maturity is split into short-term and medium- to long-term. Moreover, there is a distinction between medium- to long- term debts that are outstanding at the time of the inflation shock and those issued after the shock. In particular, the dynamic debt equation is specified as follows:

$$
b_{t}=\left\{\begin{array}{c}
-p b_{t}+b_{t-1}^{S T}\left(\frac{1+r_{t}^{S T}}{1+g_{t}}\right)+b_{t-1}^{M T-L T, \text { old }}\left[\frac{1+i_{t}^{\text {imp }}}{\left(1+g_{t}\right)\left(1+\pi_{t}^{\text {base }}+\pi_{t}^{\text {surprise }}\right)}\right] \\
+b_{t-1}^{M T-L T, \text { new }}\left[\frac{1+i_{t}^{\text {imp }}+\pi_{t}^{\text {surprise }}}{\left(1+g_{t}\right)\left(1+\pi_{t}^{\text {base }}+\pi_{t}^{\text {surprise }}\right)}\right]+b_{t-1}^{\text {indexed }}\left(\frac{1+r_{t}^{M T-L T}}{1+g_{t}}\right)
\end{array}\right\}
$$

In (4.1), $b_{t}, b_{t-1}^{S T}, b_{t-1}^{M T-L T, \text { old }}, b_{t-1}^{M T-L T, \text { new }}, b_{t-1}^{\text {indexed }}$ are the debt- to- GDP ratio, short-term debtto- GDP ratio, medium- and long-term outstanding debt- to- GDP ratios, post-inflation shock issuances of medium- and long-term debt to GDP ratio, and inflation-indexed or foreign currency debt-to-GDP ratio. The variables $r_{t}^{S T}, i_{t}^{i m p}, r_{t}^{M T-L T}$ represent real interest rates on short-term debt, implied nominal interest rates on medium- and long-term debt, and real interest rates on mediumand long-term debt. Respectively, $\pi_{t}^{\text {base }}, \pi_{t}^{\text {surprise }}, g_{t}, p b_{t}$ are baseline inflation, inflation shock ("surprise inflation"), real output growth, and primary balance- to- GDP ratio.

In the baseline scenario, inflation shock in time $\mathrm{t}\left(\pi_{t}^{\text {surprise }}\right)$ affects the debt-to-GDP ratio only via medium- and long-term debt that has already been issued prior to the inflation shock $\left(b_{t-1}^{M T-L T, o l d}\right)$ because interest rates on the short-term and inflation-indexed debts are adjusted at the time of new issuance or via indexation. Moreover, foreign-currency-denominated debt cannot be inflated away. Thus, the medium- and long-term, non-indexed, domestic-currency-denominated debt should be the easiest to inflate away. The decomposition of gross debt by maturity, indexation, and currency composition shows that medium- and long-term, non-indexed, domestic-currencydenominated debt is the most common type of debt in G-7 countries (Figure 2). Thus, in principle, it is possible for inflation to reduce debt. However, in countries with substantial liquid assets, the inflation impact on net debt could be significantly different from that on gross debt. We therefore analyze the impact of inflation on both gross and net debt ratios. 
Figure 2

Percentage Breakdown of Central Government Debt, 2010
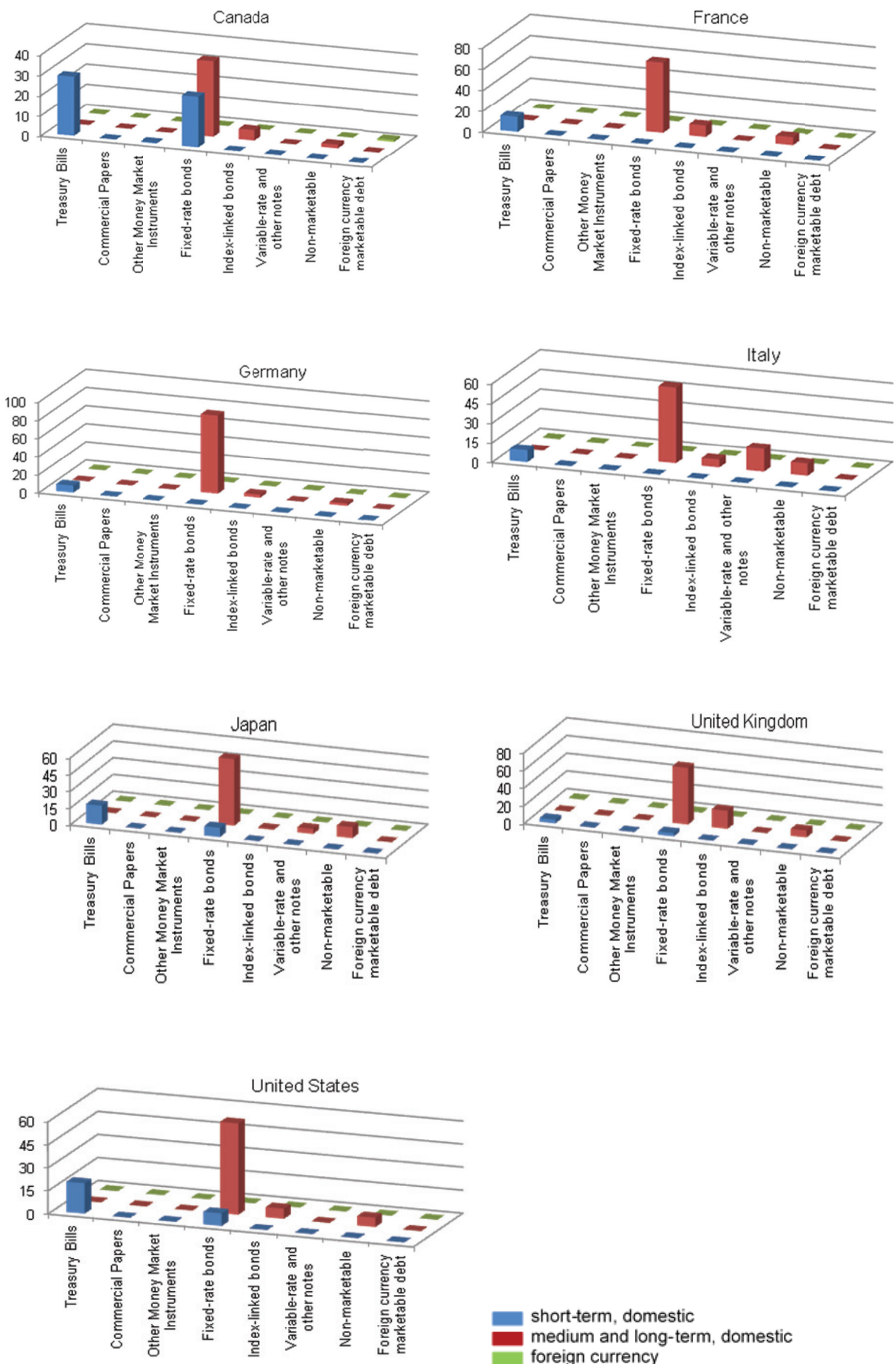

short-term, domestic

medium and long-term, domestic

foreign currency

Source: authors' calculations based on OECD central government debt data. 


\subsubsection{Sources of data}

Data on $b_{t}, p b_{t}, r_{t}^{S T}, r_{t}^{M T-L T}, \pi_{t}^{\text {base }}$ come from projections in the October 2012 WEO. Decomposition of gross debt ( $b_{t}$ into $b_{t-1}^{S T}, b_{t-1}^{M T-L T, \text { old }}, b_{t-1}^{M T-L T, \text { new }}, b_{t-1}^{\text {indexed }}$ ), as well as data on the average maturity of domestic debt, are obtained from the latest OECD dataset on central government debt. ${ }^{5}$ Since this database is only available up to 2010, we used the 2010 shares and average maturity data as constant parameters for the simulation period. For the simulation on net debt, data on the average maturity and currency breakdown of financial assets were not available in the OECD database. We then draw from the WEO, the IMF Article IV Staff Reports, and the IMF country desks' database. Where data are not available, we assume the same structure for gross debt and financial assets. Lastly, $i_{t}^{i m p}$ is endogenously obtained from (4.1).

\subsubsection{Key assumptions}

The baseline simulation assumes that the structure of government debt (shares of mediumand long-term debts; average maturity; ${ }^{6}$ and the portion that is foreign-currency-denominated and inflation-indexed) remains constant over time. This implies that maturing debt is rolled over and that maturing medium- and long-term debts are replaced each year to keep the debt structure constant. Economic growth rates are unaffected by changes in inflation, and interest rates on a newly issued debt adjust one-for-one (full Fisher effect) to increases in inflation. The validity of some of these assumptions is discussed in Section V.

\subsubsection{Inflation shocks simulated}

The simulation exercise starts from the $W E O$ baseline for the sample countries, with inflation averaging 1.6 percent over 2012-2017, and general government gross (net) debt averaging 117 (87) percent of GDP in 2017. It investigates the impact on gross and net debt ratios if inflation were to average 4, 6, or 8 percent annually over 2012-2017.

\subsection{Baseline Results - Full Fisher Effect}

\subsubsection{Simulation of the impact of low inflation}

To illustrate how low inflation could make it difficult to reverse public debt, we lower inflation to zero from the $W E O$ baseline projections. This would increase the average gross debt-to-GDP ratio in 2017 by about 6 percentage points relative to $W E O$ projections. Debt increase varies from 2 percentage points for Canada to 4-5 percentage points for France, Germany, the U.K., and the U.S. Italy's debt increase is 8 percentage points, and Japan's is 12.5 percentage points. As regards to the net debt, the average increase is about 5 percentage points by the end of the period for the sample (Table 2).

\footnotetext{
5 We try to use the common data sources to the greatest extent possible in order to facilitate international comparison. This may have led to differences in data definitions used by IMF country teams.

6 The average maturity in all countries (except the UK) is below or around seven years.
} 
Table 2

Zero Inflation Simulation Results ${ }^{1}$

\begin{tabular}{|c|c|c|c|c|c|c|c|c|c|}
\hline & \multicolumn{4}{|c|}{2012} & \multirow{3}{*}{$\begin{array}{c}2012-17 \\
\text { Inflation, } \\
\text { WEO }^{3}\end{array}$} & \multicolumn{4}{|c|}{2017} \\
\hline & \multicolumn{2}{|c|}{ Gross } & \multicolumn{2}{|c|}{ Net } & & \multicolumn{2}{|c|}{ WEO } & \multicolumn{2}{|c|}{$\begin{array}{c}\text { Debt Reduction: } \\
0 \% \text { Scenario }^{4}\end{array}$} \\
\hline & Total & MT-LT & Total & MT-LT & & Gross & Net & Gross & Net \\
\hline Canada & 87.5 & 34.3 & 35.8 & $-12.4^{5}$ & 1.9 & 78.1 & 36.3 & -1.9 & 0.4 \\
\hline France & 90.0 & 67.4 & 83.7 & 63.5 & 1.8 & 86.5 & 80.2 & -4.5 & -4.2 \\
\hline Germany & 83.0 & 73.6 & 58.4 & 58.9 & 1.6 & 73.7 & 56.2 & -4.8 & -4.1 \\
\hline Italy & 126.3 & 108.7 & 103.1 & 93.7 & 1.4 & 120.6 & 98.7 & -8.2 & -7.1 \\
\hline Japan & 236.6 & 175.2 & 135.4 & 98.6 & 0.3 & 250.3 & 158.7 & -12.5 & -9.3 \\
\hline United Kingdom & 88.7 & 63.5 & 83.7 & 63.5 & 2.5 & 93.7 & 88.7 & -4.5 & -4.4 \\
\hline United States & 107.2 & 70.2 & 83.8 & 52.5 & 1.7 & 114.0 & 89.4 & -4.4 & -3.4 \\
\hline Average & 117.0 & 84.7 & 83.4 & 59.8 & 1.6 & 116.7 & 86.9 & -5.8 & -4.6 \\
\hline
\end{tabular}

WEO inflation figures reported in percent; all other figures are percentages of GDP

Medium and long-term debt in domestic currency, non-indexed.

GDP deflator inflation, average over the period as projected in the WEO.

This implies an decrease in inflation by 1.6 percentage points over projected average inflation of 1.6 percent.

Canada has more medium and long-term financial assets than medium and long term debt.

Sources: IMF, September WEO, OECD, and Fund staff estimates.

\subsubsection{Simulation of the impact of high inflation}

The debt-erosion channel could have a stronger impact than seigniorage does. As shown in Table 2, raising the average inflation rate to 6 percent annually - about 4.5 percentage points higher than that of the $W E O$ baseline - would reduce the average gross debt-to-GDP ratio in 2017 by about 14.5 percentage points relative to the $W E O$ projections. Debt reduction varies from 5 percentage points for Canada to 11-12 percentage points for France, Germany, the U.K., and the U.S., to 20 percentage points for Italy, and 30 percentage points for Japan.

Regarding the net debt, the average reduction is about 11 percentage points by the end of the period for most countries (aside from Japan and Italy, where the effect would be larger) (Table 3). The erosion effect would drop rapidly after five years because an increasingly large share of securities would have been issued at higher interest rates, including the replacement of the maturing debt that had been issued at lower rates. At this time, debt-to-GDP ratios could start increasing again, underscoring the temporary nature of the relief provided by inflation. Real interest rates on debt could rise, due to an inflation risk premium, and growth could be eroded from higher inflation or uncertainty over inflation. 
Table 3

Baseline Simulation Results ${ }^{1}$

\begin{tabular}{|c|c|c|c|c|c|c|c|c|c|}
\hline & \multicolumn{4}{|c|}{2012} & \multirow{3}{*}{$\begin{array}{c}2012-17 \\
\begin{array}{c}\text { Inflation, } \\
\mathrm{WEO}^{3}\end{array}\end{array}$} & \multicolumn{4}{|c|}{2017} \\
\hline & \multicolumn{2}{|c|}{ Gross } & \multicolumn{2}{|c|}{ Net } & & \multicolumn{2}{|c|}{ WEO } & \multicolumn{2}{|c|}{$\begin{array}{c}\text { Debt Reduction: } \\
6 \% \text { Scenario }^{4}\end{array}$} \\
\hline & Total & MT-LT & Total & MT-LT & & Gross & Net & Gross & Net \\
\hline Canada & 87.5 & 34.3 & 35.8 & $-12.4^{5}$ & 1.9 & 78.1 & 36.3 & 4.9 & -0.8 \\
\hline France & 90.0 & 67.4 & 83.7 & 63.5 & 1.8 & 86.5 & 80.2 & 11.2 & 10.5 \\
\hline Germany & 83.0 & 73.6 & 58.4 & 58.9 & 1.6 & 73.7 & 56.2 & 11.8 & 9.9 \\
\hline Italy & 126.3 & 108.7 & 103.1 & 93.7 & 1.4 & 120.6 & 98.7 & 19.9 & 17.4 \\
\hline Japan & 236.6 & 175.2 & 135.4 & 98.6 & 0.3 & 250.3 & 158.7 & 30.8 & 22.9 \\
\hline United Kingdom & 88.7 & 63.5 & 83.7 & 63.5 & 2.5 & 93.7 & 88.7 & 11.1 & 11.1 \\
\hline United States & 107.2 & 70.2 & 83.8 & 52.5 & 1.7 & 114.0 & 89.4 & 11.0 & 8.4 \\
\hline Average & 117.0 & 84.7 & 83.4 & 59.8 & 1.6 & 116.7 & 86.9 & 14.4 & 11.3 \\
\hline
\end{tabular}

WEO inflation figures reported in percent; all other figures are percentages of GDP

Medium and long-term debt in domestic currency, non-indexed.

GDP deflator inflation, average over the period as projected in the WEO.

This implies an increase in inflation by 4.4 percentage points over projected average inflation of 1.6 percent.

5 Canada has more medium and long-term financial assets than medium and long term debt.

Sources: IMF, September WEO, OECD, and Fund staff estimates.

The inflation impact on debt is positively correlated with the initial share of medium- and long-term, non-indexed, and domestic-currency debts. This is because inflation reduces debt primarily by eroding the real value of outstanding medium- and long-term debt. As shown in Figure 3, the debt reduction increases with the share of medium- and long-term debts. To illustrate the role of the maturity structure, we simulate the debt reduction under alternative shares of shortterm debt (net of inflation-indexed debt) for the U.S. According to Figure 4, a 10 percent increase in the share of short-term debt would reduce the inflation impact on debt by about 1.5 percentage points.

\section{Figure 3}

Debt Reduction as a Function of Medium- and Long-Term Debt Share (6 Percent Inflation, baseline scenario, 2012-17)

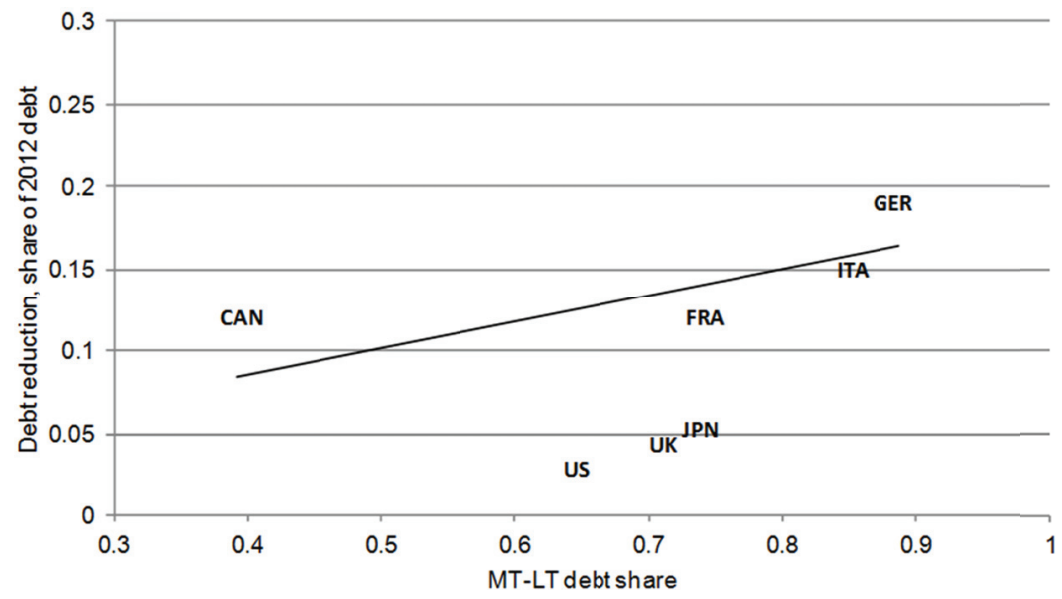

Source: authors' calculations based on OECD central government debt data. 


\section{Figure 4}

Debt Reduction Outcomes with Varying Short- Term Debt Shares, United States (6 percent inflation) (6 Percent Inflation, baseline scenario, 2012-17)

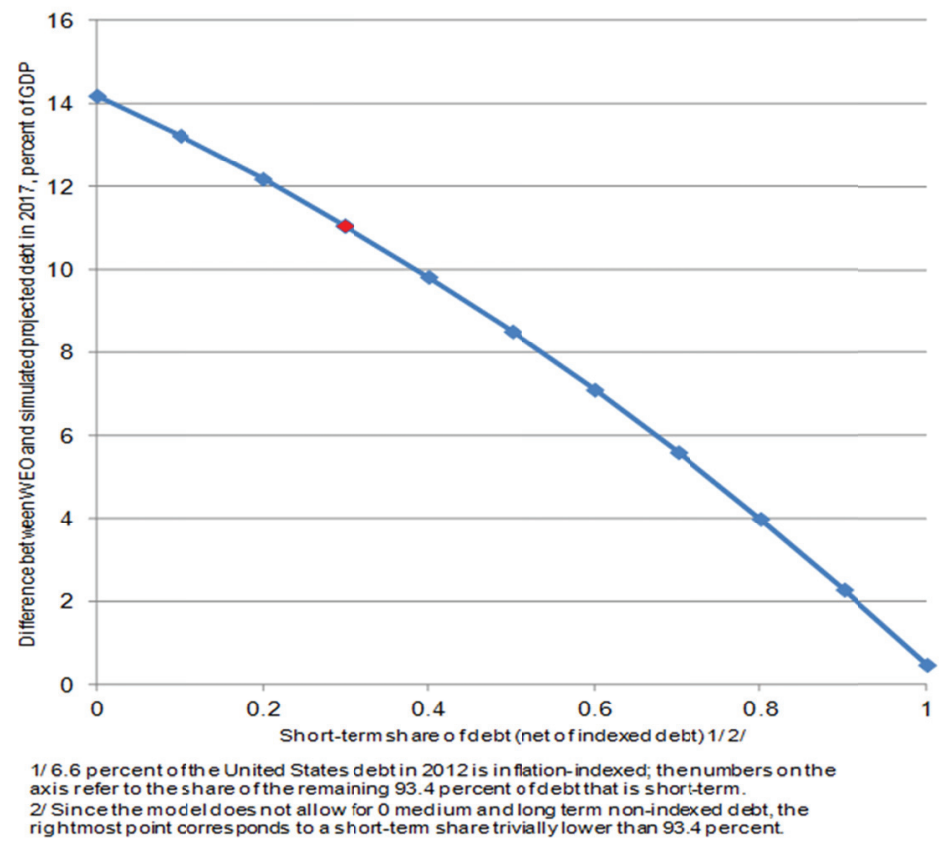

Source: authors' calculations.

Suppose now we would like to target a high level of decrease in debt-to-GDP ratio, for example, by 30 percentage points. How much inflation would be needed to achieve this level of debt reduction? This sizable debt "liquidation" would require double-digit inflation. Simulations find that raising the inflation rate to about 11 percent between 2013 and 2017 or raising it to about 18 percent for two years, and then maintaining it at 6 percent for the remaining three years, would reduce the 2017 gross debt-to-GDP ratio for the sample by 30 percentage points (Table 4). For net debt, the required inflation is even more extreme; it would take 15 percent inflation over 2013-17, or 30 percent for the first two years, followed by 6 percent of the remaining three years. These results suggest that inflation could hardly solve the debt problem alone, as it would raise significant risks for the real sector through the un-anchoring of inflation expectations. 
Table 4

30 Percent of GDP Debt Reduction Scenarios ${ }^{1}$

\begin{tabular}{|c|c|c|c|c|c|c|c|c|c|c|c|}
\hline & \multicolumn{4}{|c|}{2012} & \multirow{3}{*}{$\begin{array}{c}2012-17 \\
\\
\text { Inflation, } \\
\text { WEO }\end{array}$} & \multicolumn{6}{|c|}{2017} \\
\hline & \multicolumn{2}{|c|}{ Gross } & \multicolumn{2}{|c|}{ Net } & & \multicolumn{2}{|c|}{ WEO } & \multicolumn{2}{|c|}{$\begin{array}{l}\text { Gross Debt Reduction, } \\
\text { Inflation Equal to: }\end{array}$} & \multicolumn{2}{|c|}{$\begin{array}{l}\text { Net Debt Reduction, } \\
\text { Inflation Equal to: }\end{array}$} \\
\hline & Total & MT-LT & Total & MT-LT & & Gross & Net & $10.7 \%^{4}$ & $\begin{array}{c}17.9 \% \\
\text { for } 2013-14 ; \\
6 \% \text { thereafter }^{5}\end{array}$ & $15.0 \%{ }^{6}$ & $\begin{array}{c}29.8 \% \\
\text { for } 2013-14 ; \\
6 \% \text { thereafter }^{7}\end{array}$ \\
\hline Canada & 87.5 & 34.3 & 35.8 & $-12.4^{8}$ & 1.9 & 78.1 & 36.3 & 10.1 & 10.2 & -2.7 & -3.2 \\
\hline France & 90.0 & 67.4 & 83.7 & 63.5 & 1.8 & 86.5 & 80.2 & 23.4 & 23.6 & 29.5 & 30.1 \\
\hline Germany & 83.0 & 73.6 & 58.4 & 58.9 & 1.6 & 73.7 & 56.2 & 24.1 & 24.2 & 26.6 & 27.3 \\
\hline Italy & 126.3 & 108.7 & 103.1 & 93.7 & 1.4 & 120.6 & 98.7 & 42.3 & 42.6 & 48.4 & 50.0 \\
\hline Japan & 236.6 & 175.2 & 135.4 & 98.6 & 0.3 & 250.3 & 158.7 & 64.6 & 63.0 & 53.8 & 51.3 \\
\hline $\begin{array}{l}\text { United } \\
\text { Kingdom }\end{array}$ & 88.7 & 63.5 & 83.7 & 63.5 & 2.5 & 93.7 & 88.7 & 23.1 & 22.7 & 31.1 & 30.6 \\
\hline $\begin{array}{l}\text { United } \\
\text { States }\end{array}$ & 107.2 & 70.2 & 83.8 & 52.5 & 1.7 & 114.0 & 89.4 & 22.7 & 23.4 & 23.2 & 23.6 \\
\hline Average & 117.0 & 84.7 & 83.4 & 59.8 & 1.6 & 116.7 & 86.9 & 30.0 & 30.0 & 30.0 & 30.0 \\
\hline
\end{tabular}

1 WEO inflation figures reported in percent; all other figures are percentages of GDP.

2 Medium and long-term debt in domestic currency, non-indexed.

3 GDP deflator inflation, average over the period as projected in the WEO.

4 This implies an increase in inflation by 9.1 percentage points over projected average inflation of 1.6 percent.

5 This implies an increase in inflation by 16.3 percentage points followed by an increase by 4.4 percentage points over projected average inflation of 1.6 percent.

6 This implies an increase in inflation by 13.4 percentage points over projected average inflation of 1.6 percent.

7 This implies an increase in inflation by 28.2 percentage points followed by an increase by 4.4 percentage points over projected average inflation of 1.6 percent.

8 Canada has more medium and long-term assets than debt.

Sources: IMF, latest WEO, OECD, and Fund staff estimates.

\subsection{Simulations of Partial Fisher effect}

The partial Fisher effect would increase the inflation impact on debt reduction. The Fisher hypothesis postulates that anticipated inflation and nominal interest rates move together. However, most empirical studies have not confirmed a one-to-one relationship as postulated by Fisher (see Summers, 1983). Indeed, fully anticipated inflation has been found to have an effect of less than one unit on nominal interest rates, and thus reduces real interest rates (Poghosyan, 2012). Possible explanations for the deviation from the Fisher effect include the "wealth effect" (Mundell, 1963; Tobin, 1965), the "tax effect" (Darby, 1975; Feldstein, 1983), and the "inverted Fisher effect" (Carmichael and Stebbing, 1983). Unconventional monetary policies and financial repression could also result in incomplete Fisher effects.

To simulate a partial Fisher effect, we modify (4.1) slightly to account for the extent to which the inflation shock increases the nominal interest rate on government debt:

$$
b_{t}=\left\{\begin{array}{c}
-p b_{t}+b_{t-1}^{S T}\left[\frac{\left(1+r_{t}^{S T}\right)\left(1+\pi_{t}^{\text {base }}+\alpha \pi_{t}^{\text {surprise }}\right)}{\left(1+g_{t}\right)\left(1+\pi_{t}^{\text {base }}+\pi_{t}^{\text {surprise }}\right)}\right]+b_{t-1}^{M T-L T, \text { old }}\left[\frac{1+i_{t}^{i m p}}{\left(1+g_{t}\right)\left(1+\pi_{t}^{\text {base }}+\pi_{t}^{\text {surprise }}\right)}\right] \\
+b_{t-1}^{M T-L T, n e w}\left[\frac{1+i_{t}^{\text {imp }}+\alpha \pi_{t}^{\text {surprise }}}{\left(1+g_{t}\right)\left(1+\pi_{t}^{\text {base }}+\pi_{t}^{\text {surprise }}\right)}\right]+b_{t-1}^{\text {indexed }}\left(\frac{1+r_{t}^{M T-L T}}{1+g_{t}}\right)
\end{array}\right\}
$$


The only difference from (4.1) is the parameter (alpha) that captures the imperfect adjustment of nominal interest rates on newly issued debt (both short-term and medium- to long-term). In the baseline scenarios, this coefficient is set to 1 (full Fisher effect).

As reported in Table 5, the simulation results suggest that raising the average inflation rate to 6 percent annually with a partial increase in nominal rates, $(\alpha=0.5)$ would reduce the 2017 gross debt-to-GDP ratio for the sample by about 18 percentage points-3.5 percentage points more than it is in the baseline scenario. The net debt reduction is about 14 percentage points, or 2.8 percentage points more than it is in the baseline scenario. With no increase in nominal rates $($ alpha $=0)$, the average gross debt reduction is 21 percentage points, while the net reduction is about 17 percentage points (Table 6). Figure 5 shows that as alpha, the adjustment parameter, increases (i.e., as we get closer to the full Fisher Effect), the size of debt reduction decreases fairly linearly.

Table 5

Debt-Reducing Impacts of Inflation with Reduced Fisher Effect $(\alpha=0.5)^{1}$

\begin{tabular}{|c|c|c|c|c|c|c|c|c|c|}
\hline & \multicolumn{4}{|c|}{2012} & \multirow{3}{*}{$\begin{array}{l}\text { 2012-17 } \\
\text { Inflation, } \\
\text { WEO }^{3}\end{array}$} & \multicolumn{4}{|c|}{2017} \\
\hline & \multicolumn{2}{|c|}{ Gross } & \multicolumn{2}{|c|}{ Net } & & \multicolumn{2}{|c|}{ WEO } & \multicolumn{2}{|c|}{$\begin{array}{l}\text { Debt Reduction: } \\
6 \% \text { Scenario }^{4}\end{array}$} \\
\hline & Total & MT-LT & Total & MT-LT & & Gross & Net & Gross & Net \\
\hline Canada & 87.5 & 34.3 & 35.8 & $-12.4^{5}$ & 1.9 & 78.1 & 36.3 & 9.4 & 3.1 \\
\hline France & 90.0 & 67.4 & 83.7 & 63.5 & 1.8 & 86.5 & 80.2 & 13.3 & 12.5 \\
\hline Germany & 83.0 & 73.6 & 58.4 & 58.9 & 1.6 & 73.7 & 56.2 & 13.1 & 10.5 \\
\hline Italy & 126.3 & 108.7 & 103.1 & 93.7 & 1.4 & 120.6 & 98.7 & 22.1 & 18.9 \\
\hline Japan & 236.6 & 175.2 & 135.4 & 98.6 & 0.3 & 250.3 & 158.7 & 38.4 & 29.5 \\
\hline United Kingdom & 88.7 & 63.5 & 83.7 & 63.5 & 2.5 & 93.7 & 88.7 & 12.6 & 12.1 \\
\hline United States & 107.2 & 70.2 & 83.8 & 52.5 & 1.7 & 114.0 & 89.4 & 15.3 & 11.9 \\
\hline Average & 117.0 & 84.7 & 83.4 & 59.8 & 1.6 & 116.7 & 86.9 & 17.8 & 14.1 \\
\hline
\end{tabular}

WEO inflation figures reported in percent; all other figures are percentages of GDP.

Medium and long-term debt in domestic currency, non-indexed.

GDP deflator inflation, average over the period as projected in the WEO.

This implies an increase in inflation by 4.4 percentage points over projected average inflation of 1.6 percent.

Canada has more medium and long-term financial assets than medium and long term debt.

Sources: IMF, September WEO, OECD, and Fund staff estimates. 
Table 6

Debt-Reducing Impacts of Inflation with Reduced Fisher Effect $(\alpha=0)^{1}$

\begin{tabular}{|c|c|c|c|c|c|c|c|c|c|}
\hline & \multicolumn{4}{|c|}{2012} & \multirow{3}{*}{$\begin{array}{l}\text { 2012-17 } \\
\text { Inflation, } \\
\text { WEO }^{3}\end{array}$} & \multicolumn{4}{|c|}{2017} \\
\hline & \multicolumn{2}{|c|}{ Gross } & \multicolumn{2}{|c|}{ Net } & & \multicolumn{2}{|c|}{ WEO } & \multicolumn{2}{|c|}{$\begin{array}{l}\text { Debt Reduction: } \\
6 \% \text { Scenario }^{4}\end{array}$} \\
\hline & Total & MT-LT & Total & MT-LT & & Gross & Net & Gross & Net \\
\hline Canada & 87.5 & 34.3 & 35.8 & $-12.4^{5}$ & 1.9 & 78.1 & 36.3 & 13.5 & 6.8 \\
\hline France & 90.0 & 67.4 & 83.7 & 63.5 & 1.8 & 86.5 & 80.2 & 15.4 & 14.3 \\
\hline Germany & 83.0 & 73.6 & 58.4 & 58.9 & 1.6 & 73.7 & 56.2 & 14.3 & 11.0 \\
\hline Italy & 126.3 & 108.7 & 103.1 & 93.7 & 1.4 & 120.6 & 98.7 & 24.2 & 20.2 \\
\hline Japan & 236.6 & 175.2 & 135.4 & 98.6 & 0.3 & 250.3 & 158.7 & 45.5 & 35.7 \\
\hline United Kingdom & 88.7 & 63.5 & 83.7 & 63.5 & 2.5 & 93.7 & 88.7 & 14.2 & 13.2 \\
\hline United States & 107.2 & 70.2 & 83.8 & 52.5 & 1.7 & 114.0 & 89.4 & 19.3 & 15.2 \\
\hline Average & 117.0 & 84.7 & 83.4 & 59.8 & 1.6 & 116.7 & 86.9 & 20.9 & 16.6 \\
\hline
\end{tabular}

WEO inflation figures reported in percent; all other figures are percentages of GDP.

Medium and long-term debt in domestic currency, non-indexed.

GDP deflator inflation, average over the period as projected in the WEO.

This implies an increase in inflation by 4.4 percentage points over projected average inflation of 1.6 percent.

5 Canada has more medium and long-term financial assets than medium and long term debt.

Sources: IMF, September WEO, OECD, and Fund staff estimates.

\section{Figure 5}

How Varying Fisher Effects Impact Debt Reduction for G7 Average (6 percent inflation scenario)

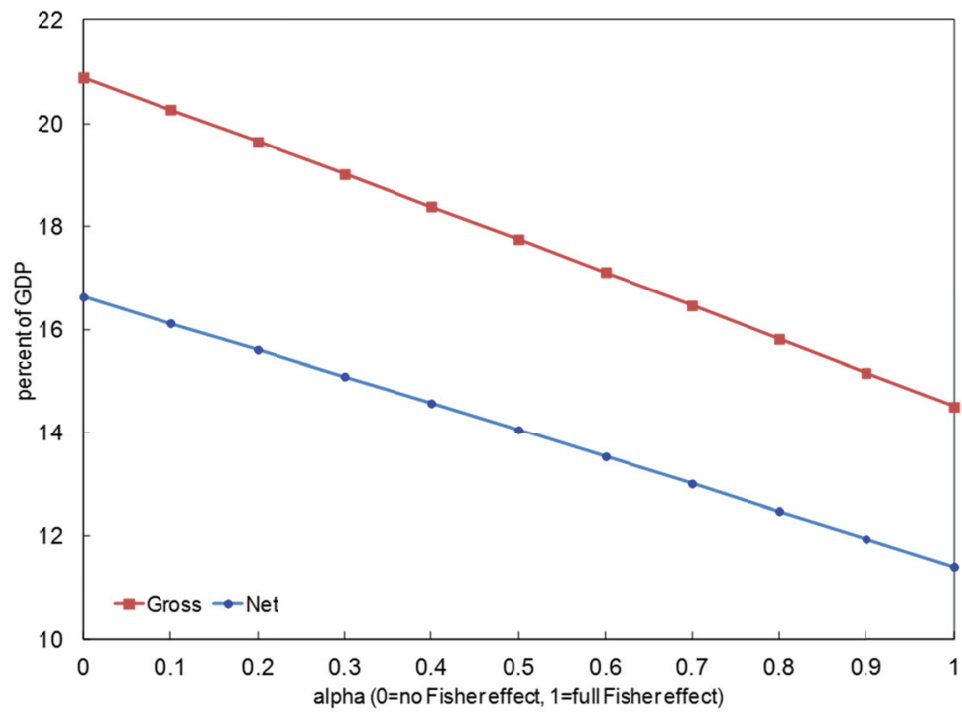

Source: authors' calculations.

\section{ROBUSTNESS OF ASSUMPTIONS}

The results of our simulations are conditional on the assumption that inflation does not affect output growth, real interest rates on the newly-issued debt, or debt maturity. For example, if debt maturity shortens as markets responds to inflation shock, the effectiveness of inflation on debt reduction will be smaller. This section discusses whether these assumptions are valid for advanced economies. 
First, we analyze the pair-wise association between (i) inflation and output growth, (ii) inflation and interest rate (real and nominal), and (iii) inflation and level of debt. In each case, the average inflation in the 1990s is plotted against the average value of the variable of interest in the 2000s. We consider two sets of countries: all OECD countries (Figure 6), and OECD countries that were members prior to 1990, except Turkey and Greece (Figure 7). The second set includes only those countries that have had advanced economies throughout the past 20 years, a sample that is closer to the economics of the countries that we focus on in this paper. We refer to the former as the "full OECD countries case," and the latter the "selected OECD countries case."

Figure 6

Inflation Scatterplots, All OECD Countries
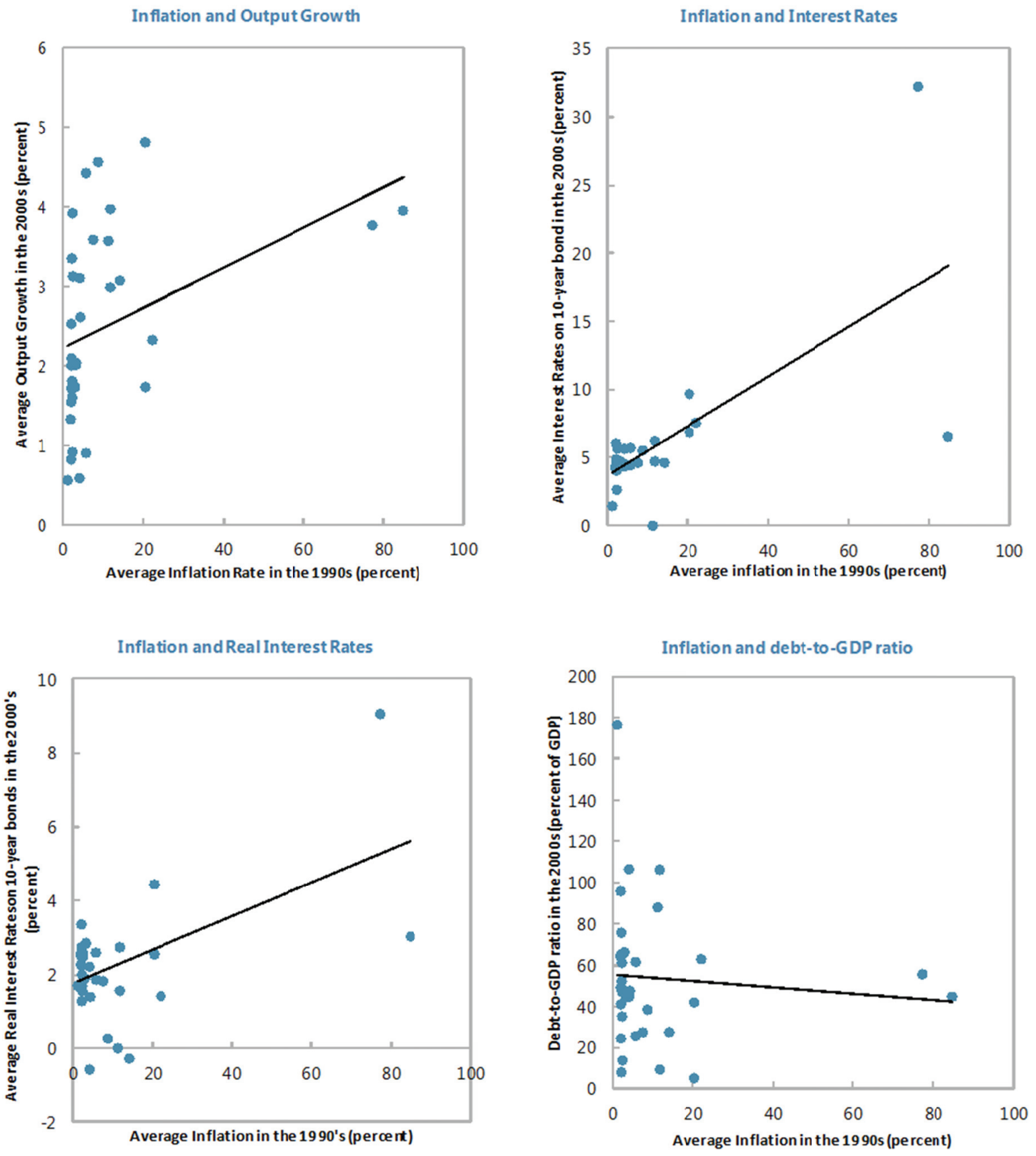

Source: World Economic Outlook, OECD. 
Figure 7

Inflation Scatterplots, Selected OECD Countries
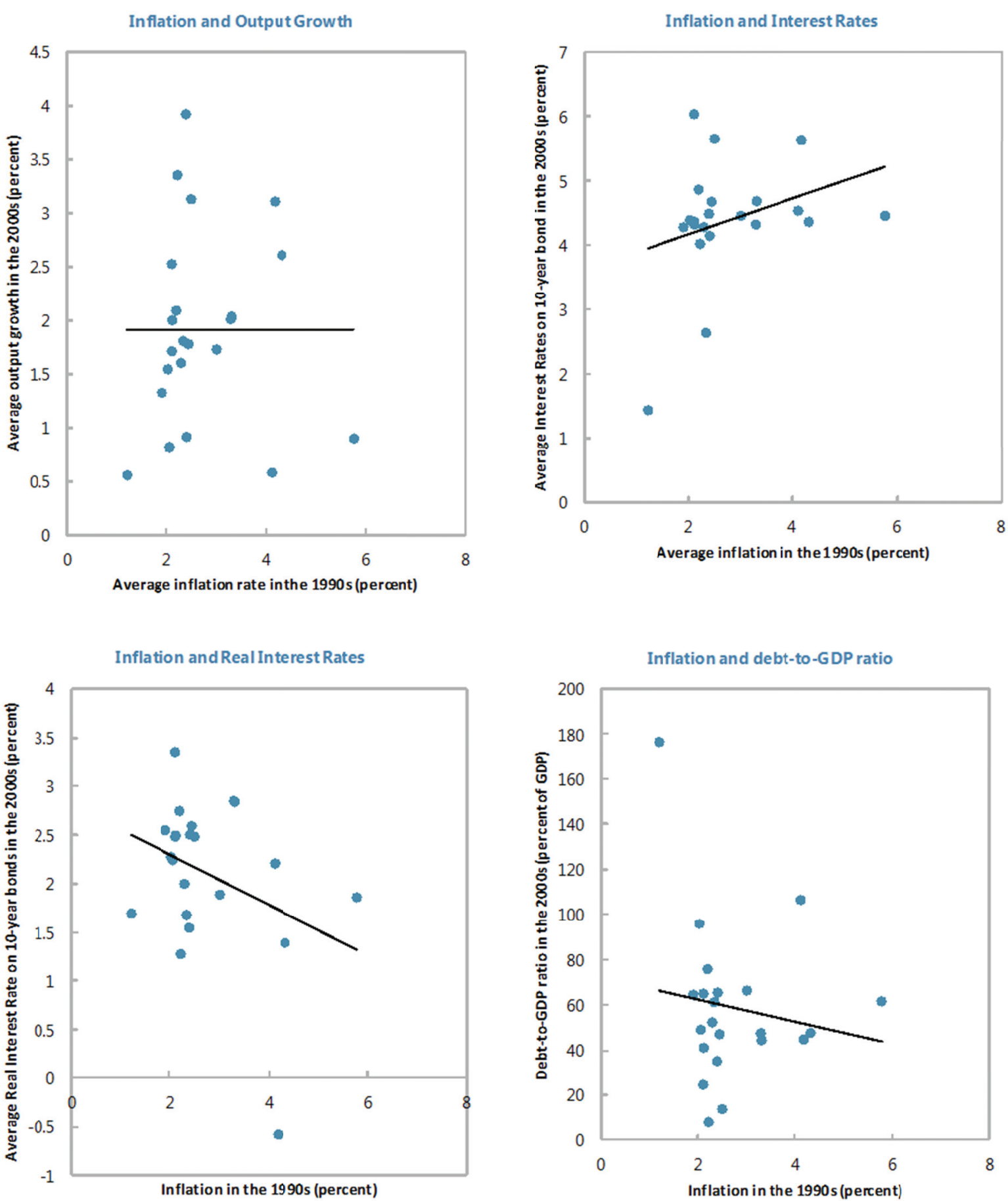

Source: World Economic Outlook, OECD.

In the full OECD countries case, inflation is positively correlated with output growth, and real and nominal interest rates, and negatively correlated with the debt-to-GDP ratio. In the selected OECD countries case, inflation is not correlated with output growth, is positively correlated with nominal interest rates, and is negatively correlated with real interest rates as well as the debt-toGDP ratio. These results show that our assumptions are broadly consistent with the stylized facts of the selected OECD countries, and fairly reasonable for the G-7 countries. In particular, inflation 
is not associated with output growth rate in future years, while positive correlation with nominal interest rates and negative correlation with real interest rates suggest that the Fisher effect is at work, but appears to be less than perfect. However, a substantial and prolonged deviation from an inflation anchor could lead to a rise in the sovereign credit risk, thus causing a larger than onefor-one effect of inflation on nominal interest rates. This would therefore diminish inflation's debt reducing benefits. ${ }^{7}$ In any case, results should be considered to be only suggestive, as the pairwise correlation does not imply causation.

Regarding the effect of inflation on debt maturity, we shift our focus back to the G-7 countries, as the debt maturity data is incomplete for a number of OECD countries. A cursory look at the time series does not reveal any clear pattern between inflation and the share of short-term debt (Figure 8). Thus, following Aizenman and Marion (2011) who also test specifications in Missale and Blanchard (1994), we run a series of regressions that are specified as follows:

$$
y_{t}=\beta_{1}+\beta_{2}^{*} \text { regressors }_{t}+\epsilon_{t}
$$

The regressors include log of debt-to-GDP ratio, CPI, lagged CPI, total government expenditure, and output growth, depending on the specification. Given the presence of unit roots in most of the variables, we test for cointegration and find that the no-cointegration hypothesis cannot be rejected at the 5 percent confidence level for overwhelming majority of regressions. Thus, we first-difference all variables to address concerns relating to potential nonstationarity and spurious regression. For the regressand, we use two alternative measures as described below.

First, using the average maturity as the regressand, we find that the effect of inflation (as measured by the CPI) on debt maturity is not statistically significant in any country (Table 7). Second, using the share of short-term debt as the regressand, we find that inflation positively affects the share of short-term debt in Italy while it is statistically insignificant in the other countries (Table 8). In summary, we do not find strong evidence that inflation leads to a maturity shortening. This result is similar to the findings of Aizenman and Marion (2011), which show no significant relationship between inflation and debt maturity for the U.S. It is also consistent with the results recorded by Missale and Blanchard (1994), which suggest no discernible effect of inflation on maturity.

\footnotetext{
As a further robustness check, we examined results for an intermediate set of countries: full OECD countries minus two clear outliers in figure 6. Results also turned out to be intermediate, i.e. inflation is positively correlated with output growth as in full OECD countries case, while there is a positive correlation with nominal interest rates and negative correlation with real interest rates, as in the selected OECD countries case. We also performed additional exercises where we replaced CPI with core CPI in all sets of countries. Results were similar to the CPI case, except that real interest rates were not negatively correlated with inflation anymore, which implies a fuller Fisher effect. Results were omitted for space consideration, but are available from the authors upon request.
} 
Figure 8

Average Maturity, Inflation, and Public Debt in G7 Countries

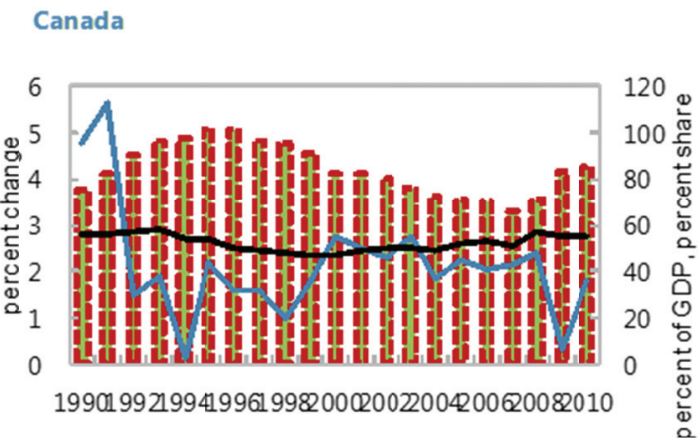

Germany

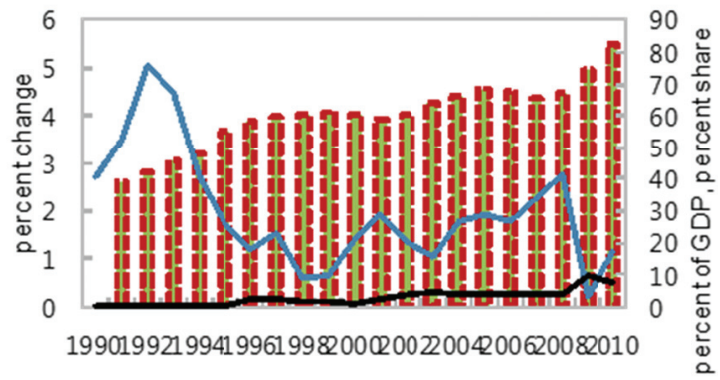

Japan

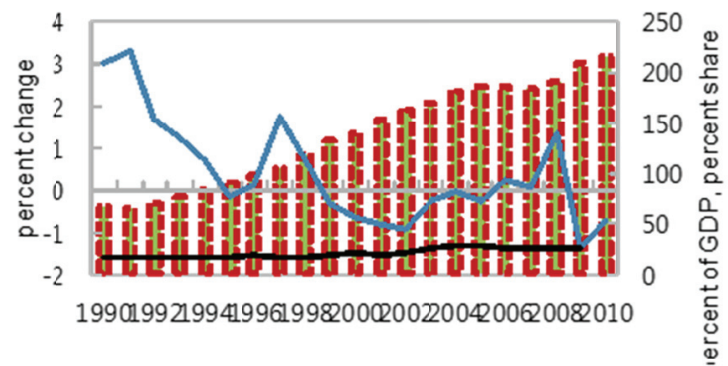

United States

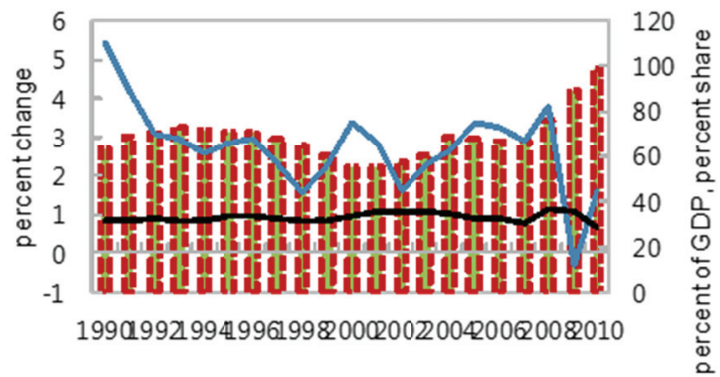

France

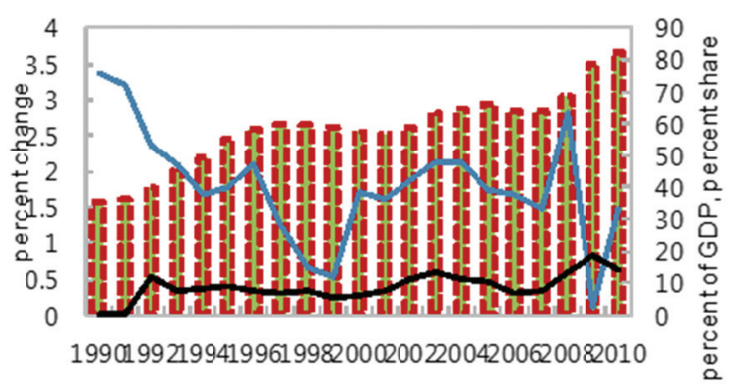

Italy

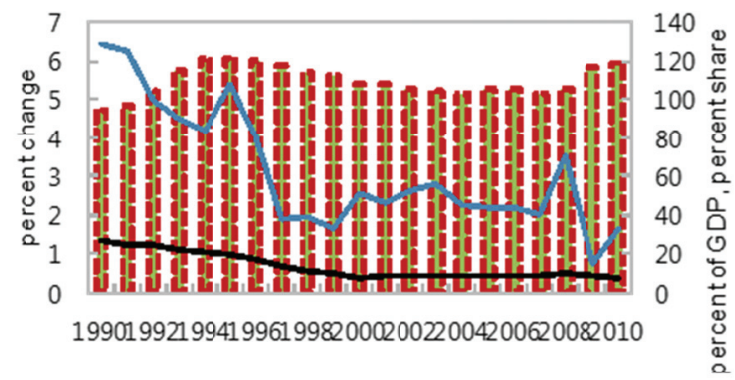

United Kingdom

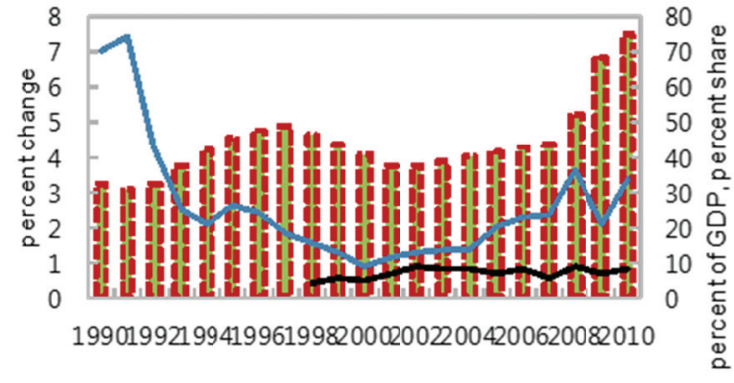
ratio<smiles>C[Te]</smiles>

Source: World Economic Outlook, OECD. 
Table 7

Robustness Regressions (Average Maturity)

\begin{tabular}{|c|c|c|c|c|c|c|}
\hline \multicolumn{7}{|c|}{ Canada } \\
\hline & $(1)$ & $(2)$ & (3) & $(4)$ & $(5)$ & (6) \\
\hline D.ln_gross_debt & $\begin{array}{l}-0.237 \\
(-1.25)\end{array}$ & $\begin{array}{l}-0.243 \\
(-1.16)\end{array}$ & $\begin{array}{l}-0.512^{*} \\
(-2.13)\end{array}$ & $\begin{array}{l}-0.170 \\
(-0.58)\end{array}$ & $\begin{array}{l}-0.156 \\
(-0.51)\end{array}$ & $\begin{array}{l}-0.494 \\
(-1.85)\end{array}$ \\
\hline D.cpi & & $\begin{array}{c}-0.000719 \\
(-0.07)\end{array}$ & $\begin{array}{c}-0.0128 \\
(-1.04)\end{array}$ & $\begin{array}{c}-0.000760 \\
(-0.07)\end{array}$ & $\begin{array}{c}-0.00141 \\
(-0.13)\end{array}$ & $\begin{array}{c}0.00362 \\
(0.42)\end{array}$ \\
\hline LD.cpi & & & $\begin{array}{c}-0.00763 \\
(-0.67)\end{array}$ & & & \\
\hline D.ln_total_exp & & & & $\begin{array}{l}-0.165 \\
(-0.37)\end{array}$ & $\begin{array}{l}-0.243 \\
(-0.45)\end{array}$ & $\begin{array}{l}0.506 \\
(1.02)\end{array}$ \\
\hline D.gdp_growth & & & & & $\begin{array}{c}-0.00190 \\
(-0.27)\end{array}$ & $\begin{array}{c}0.00220 \\
(0.38)\end{array}$ \\
\hline time & & & & & & $\begin{array}{c}-0.00640^{* *} \\
(-3.09)\end{array}$ \\
\hline _cons & $\begin{array}{l}0.0217 \\
(1.83)\end{array}$ & $\begin{array}{l}0.0217 \\
(1.77)\end{array}$ & $\begin{array}{l}0.0128 \\
(1.05)\end{array}$ & $\begin{array}{c}0.0204 \\
(1.57)\end{array}$ & $\begin{array}{c}0.0202 \\
(1.50)\end{array}$ & $\begin{array}{c}12.83^{* *} \\
(3.09)\end{array}$ \\
\hline $\mathrm{N}$ & 20 & 20 & 19 & 20 & 20 & 20 \\
\hline
\end{tabular}

France

\begin{tabular}{|c|c|c|c|c|c|c|}
\hline & (1) & (2) & (3) & (4) & (5) & (6) \\
\hline D.ln_gross_debt & $\begin{array}{l}-0.216 \\
(-1.19)\end{array}$ & $\begin{array}{l}-0.230 \\
(-1.15)\end{array}$ & $\begin{array}{l}-0.297 \\
(-1.72)\end{array}$ & $\begin{array}{l}-0.156 \\
(-0.49)\end{array}$ & $\begin{array}{l}-0.446 \\
(-1.60)\end{array}$ & $\begin{array}{l}-0.345 \\
(-1.03)\end{array}$ \\
\hline D.cpi & & $\begin{array}{c}-0.00234 \\
(-0.20)\end{array}$ & $\begin{array}{c}-0.0202 \\
(-1.64)\end{array}$ & $\begin{array}{c}-0.00341 \\
(-0.27)\end{array}$ & $\begin{array}{c}-0.00580 \\
(-0.55)\end{array}$ & $\begin{array}{c}-0.00654 \\
(-0.60)\end{array}$ \\
\hline LD.cpi & & & $\begin{array}{c}-0.0318^{*} \\
(-2.59)\end{array}$ & & & \\
\hline D.ln_total_exp & & & & $\begin{array}{l}-0.244 \\
(-0.31)\end{array}$ & $\begin{array}{l}1.250 \\
(1.48)\end{array}$ & $\begin{array}{l}0.944 \\
(0.93)\end{array}$ \\
\hline D.gdp_growth & & & & & $\begin{array}{c}0.0178^{*} \\
(2.80)\end{array}$ & $\begin{array}{c}0.0165^{*} \\
(2.42)\end{array}$ \\
\hline time & & & & & & $\begin{array}{c}0.00115 \\
(0.58)\end{array}$ \\
\hline _cons & $\begin{array}{c}0.0147 \\
(1.21)\end{array}$ & $\begin{array}{l}0.0151 \\
(1.19)\end{array}$ & $\begin{array}{l}0.0115 \\
(1.05)\end{array}$ & $\begin{array}{c}0.0132 \\
(0.91)\end{array}$ & $\begin{array}{c}0.0177 \\
(1.48)\end{array}$ & $\begin{array}{l}-2.288 \\
(-0.58)\end{array}$ \\
\hline $\mathrm{N}$ & 18 & 18 & 18 & 18 & 18 & 18 \\
\hline
\end{tabular}

\section{Germany}

\begin{tabular}{|c|c|c|c|c|c|c|}
\hline & (1) & (2) & (3) & (4) & (5) & (6) \\
\hline D.ln_gross_debt & $\begin{array}{l}-0.122 \\
(-0.36)\end{array}$ & $\begin{array}{l}-0.203 \\
(-0.53)\end{array}$ & $\begin{array}{l}-0.246 \\
(-0.58)\end{array}$ & $\begin{array}{l}-0.179 \\
(-0.38)\end{array}$ & $\begin{array}{l}-0.348 \\
(-0.74)\end{array}$ & $\begin{array}{l}-0.483 \\
(-1.02)\end{array}$ \\
\hline D.cpi & & $\begin{array}{c}-0.00938 \\
(-0.51)\end{array}$ & $\begin{array}{c}-0.0104 \\
(-0.53)\end{array}$ & $\begin{array}{c}-0.00966 \\
(-0.50)\end{array}$ & $\begin{array}{c}-0.0155 \\
(-0.81)\end{array}$ & $\begin{array}{l}-0.0164 \\
(-0.88)\end{array}$ \\
\hline LD.cpi & & & $\begin{array}{c}-0.00517 \\
(-0.27)\end{array}$ & & & \\
\hline D.ln_total_exp & & & & $\begin{array}{c}-0.0383 \\
(-0.09)\end{array}$ & $\begin{array}{l}0.204 \\
(0.47)\end{array}$ & $\begin{array}{l}0.291 \\
(0.68)\end{array}$ \\
\hline D.gdp_growth & & & & & $\begin{array}{c}0.00853 \\
(1.43)\end{array}$ & $\begin{array}{c}0.0104 \\
(1.73)\end{array}$ \\
\hline time & & & & & & $\begin{array}{c}-0.00393 \\
(-1.31)\end{array}$ \\
\hline _cons & $\begin{array}{c}0.0208 \\
(1.01)\end{array}$ & $\begin{array}{l}0.0227 \\
(1.06)\end{array}$ & $\begin{array}{c}0.0236 \\
(1.06)\end{array}$ & $\begin{array}{c}0.0218 \\
(0.91)\end{array}$ & $\begin{array}{c}0.0276 \\
(1.17)\end{array}$ & $\begin{array}{l}7.887 \\
(1.31)\end{array}$ \\
\hline $\mathrm{N}$ & 19 & 19 & 19 & 19 & 19 & 19 \\
\hline
\end{tabular}


Table 7

Robustness Regressions (Average Maturity) (Cont.)

\begin{tabular}{|c|c|c|c|c|c|c|}
\hline \multicolumn{7}{|c|}{ Italy } \\
\hline & (1) & (2) & (3) & (4) & $(5)$ & (6) \\
\hline D.ln_gross_debt & $\begin{array}{l}0.719 \\
(1.53)\end{array}$ & $\begin{array}{l}0.689 \\
(1.33)\end{array}$ & $\begin{array}{l}0.591 \\
(1.11)\end{array}$ & $\begin{array}{l}1.332^{*} \\
(2.58)\end{array}$ & $\begin{array}{l}1.358^{*} \\
(2.42)\end{array}$ & $\begin{array}{l}1.176 \\
(1.92)\end{array}$ \\
\hline D.cpi & & $\begin{array}{c}-0.00320 \\
(-0.16)\end{array}$ & $\begin{array}{c}-0.0107 \\
(-0.49)\end{array}$ & $\begin{array}{c}-0.00884 \\
(-0.51)\end{array}$ & $\begin{array}{c}-0.00796 \\
(-0.42)\end{array}$ & $\begin{array}{c}-0.00727 \\
(-0.38)\end{array}$ \\
\hline LD.cpi & & & $\begin{array}{c}-0.0169 \\
(-0.81)\end{array}$ & & & \\
\hline D.ln_total_exp & & & & $\begin{array}{l}-1.722^{*} \\
(-2.56)\end{array}$ & $\begin{array}{l}-1.817 \\
(-1.91)\end{array}$ & $\begin{array}{l}-1.405 \\
(-1.28)\end{array}$ \\
\hline D.gdp_growth & & & & & $\begin{array}{c}-0.00153 \\
(-0.15)\end{array}$ & $\begin{array}{c}0.00157 \\
(0.14)\end{array}$ \\
\hline time & & & & & & $\begin{array}{c}-0.00272 \\
(-0.80)\end{array}$ \\
\hline _cons & $\begin{array}{c}0.0432^{*} \\
(2.27)\end{array}$ & $\begin{array}{c}0.0428^{*} \\
(2.17)\end{array}$ & $\begin{array}{l}0.0331 \\
(1.52)\end{array}$ & $\begin{array}{c}0.0305 \\
(1.71)\end{array}$ & $\begin{array}{c}0.0302 \\
(1.63)\end{array}$ & $\begin{array}{l}5.472 \\
(0.80)\end{array}$ \\
\hline $\mathrm{N}$ & 20 & 20 & 19 & 20 & 20 & 20 \\
\hline \multicolumn{7}{|c|}{ Japan } \\
\hline & (1) & (2) & (3) & (4) & (5) & (6) \\
\hline D.ln_gross_debt & $\begin{array}{l}-0.404 \\
(-2.04)\end{array}$ & $\begin{array}{l}-0.410 \\
(-1.80)\end{array}$ & $\begin{array}{l}-0.520^{*} \\
(-2.70)\end{array}$ & $\begin{array}{l}-0.412 \\
(-1.71)\end{array}$ & $\begin{array}{l}-0.382 \\
(-1.67)\end{array}$ & $\begin{array}{l}-0.283 \\
(-1.24)\end{array}$ \\
\hline D.cpi & & $\begin{array}{c}-0.000531 \\
(-0.06)\end{array}$ & $\begin{array}{c}0.00376 \\
(0.55)\end{array}$ & $\begin{array}{c}-0.000362 \\
(-0.04)\end{array}$ & $\begin{array}{c}0.000772 \\
(0.08)\end{array}$ & $\begin{array}{c}0.000305 \\
(0.03)\end{array}$ \\
\hline LD.cpi & & & $\begin{array}{c}0.0217^{*} \\
(2.85)\end{array}$ & & & \\
\hline D.ln_total_exp & & & & $\begin{array}{c}0.00906 \\
(0.04)\end{array}$ & $\begin{array}{l}-0.130 \\
(-0.54)\end{array}$ & $\begin{array}{l}-0.177 \\
(-0.77)\end{array}$ \\
\hline D.gdp_growth & & & & & $\begin{array}{c}-0.00703 \\
(-1.65)\end{array}$ & $\begin{array}{c}-0.00655 \\
(-1.61)\end{array}$ \\
\hline time & & & & & & $\begin{array}{c}0.00208 \\
(1.55)\end{array}$ \\
\hline _cons & $\begin{array}{l}0.0287 \\
(2.06)\end{array}$ & $\begin{array}{l}0.0290 \\
(1.94)\end{array}$ & $\begin{array}{c}0.0421^{* *} \\
(3.28)\end{array}$ & $\begin{array}{l}0.0290 \\
(1.88)\end{array}$ & $\begin{array}{l}0.0254 \\
(1.72)\end{array}$ & $\begin{array}{l}-4.139 \\
(-1.54)\end{array}$ \\
\hline $\mathrm{N}$ & 19 & 19 & 18 & 19 & 19 & 19 \\
\hline \multicolumn{7}{|c|}{ United Kingdom } \\
\hline & (1) & (2) & (3) & (4) & $(5)$ & (6) \\
\hline D.ln_gross_debt & $\begin{array}{l}-0.174^{*} \\
(-2.49)\end{array}$ & $\begin{array}{c}-0.172^{*} \\
(-2.40)\end{array}$ & $\begin{array}{l}-0.215^{*} \\
(-2.66)\end{array}$ & $\begin{array}{l}-0.157 \\
(-1.83)\end{array}$ & $\begin{array}{l}-0.157 \\
(-1.76)\end{array}$ & $\begin{array}{c}-0.307^{*} \\
(-2.85)\end{array}$ \\
\hline D.cpi & & $\begin{array}{c}0.00514 \\
(0.54)\end{array}$ & $\begin{array}{c}0.0124 \\
(1.08)\end{array}$ & $\begin{array}{c}0.00555 \\
(0.56)\end{array}$ & $\begin{array}{c}0.00699 \\
(0.64)\end{array}$ & $\begin{array}{c}-0.00240 \\
(-0.23)\end{array}$ \\
\hline LD.cpi & & & $\begin{array}{c}0.0154 \\
(1.11)\end{array}$ & & & \\
\hline D.ln_total_exp & & & & $\begin{array}{c}-0.0614 \\
(-0.35)\end{array}$ & $\begin{array}{l}-0.113 \\
(-0.52)\end{array}$ & $\begin{array}{l}-0.376 \\
(-1.62)\end{array}$ \\
\hline D.gdp_growth & & & & & $\begin{array}{c}-0.00172 \\
(-0.42)\end{array}$ & $\begin{array}{c}-0.00614 \\
(-1.47)\end{array}$ \\
\hline time & & & & & & $\begin{array}{c}0.00554 \\
(2.02)\end{array}$ \\
\hline _cons & $\begin{array}{c}0.0307^{* * *} \\
(4.64)\end{array}$ & $\begin{array}{c}0.0304^{* * *} \\
(4.46)\end{array}$ & $\begin{array}{c}0.0314^{* * *} \\
(4.61)\end{array}$ & $\begin{array}{c}0.0303^{* *} \\
(4.28)\end{array}$ & $\begin{array}{c}0.0305^{* *} \\
(4.13)\end{array}$ & $\begin{array}{l}-11.05 \\
(-2.02)\end{array}$ \\
\hline $\mathrm{N}$ & 15 & 15 & 15 & 15 & 15 & 15 \\
\hline
\end{tabular}


Table 7

Robustness Regressions (Average Maturity) (Cont.)

\begin{tabular}{|c|c|c|c|c|c|c|}
\hline \multicolumn{7}{|c|}{ United States } \\
\hline & (1) & (2) & (3) & (4) & (5) & (6) \\
\hline D.ln_gross_debt & $\begin{array}{l}-0.181 \\
(-1.04)\end{array}$ & $\begin{array}{l}-0.196 \\
(-1.05)\end{array}$ & $\begin{array}{l}-0.321 \\
(-1.69)\end{array}$ & $\begin{array}{c}-0.0317 \\
(-0.13)\end{array}$ & $\begin{array}{l}-0.173 \\
(-0.64)\end{array}$ & $\begin{array}{l}-0.213 \\
(-0.86)\end{array}$ \\
\hline D.cpi & & $\begin{array}{c}-0.00267 \\
(-0.27)\end{array}$ & $\begin{array}{c}-0.0136 \\
(-1.22)\end{array}$ & $\begin{array}{c}-0.00772 \\
(-0.69)\end{array}$ & $\begin{array}{c}-0.00993 \\
(-0.89)\end{array}$ & $\begin{array}{c}-0.0200 \\
(-1.76)\end{array}$ \\
\hline LD.cpi & & & $\begin{array}{c}-0.0229 \\
(-1.96)\end{array}$ & & & \\
\hline D.In_total_exp & & & & $\begin{array}{l}-0.653 \\
(-1.05)\end{array}$ & $\begin{array}{l}-0.196 \\
(-0.27)\end{array}$ & $\begin{array}{l}-0.858 \\
(-1.15)\end{array}$ \\
\hline D.gdp_growth & & & & & $\begin{array}{c}0.00861 \\
(1.13)\end{array}$ & $\begin{array}{c}0.00689 \\
(0.99)\end{array}$ \\
\hline time & & & & & & $\begin{array}{c}0.00481 \\
(2.01)\end{array}$ \\
\hline _cons & $\begin{array}{c}-0.00449 \\
(-0.37)\end{array}$ & $\begin{array}{c}-0.00468 \\
(-0.38)\end{array}$ & $\begin{array}{c}-0.0105 \\
(-0.85)\end{array}$ & $\begin{array}{c}-0.00489 \\
(-0.39)\end{array}$ & $\begin{array}{c}-0.00548 \\
(-0.45)\end{array}$ & $\begin{array}{l}-9.615 \\
(-2.01)\end{array}$ \\
\hline $\mathrm{N}$ & 20 & 20 & 19 & 20 & 20 & 20 \\
\hline
\end{tabular}

t statistics in parentheses

$=$ "* $\mathrm{p}<0.0{ }^{* *} \mathrm{p}<0.01 \quad{ }^{* * *} \mathrm{p}<0.001$ "

Table 8

Robustness Regressions (Short-term Share)

\begin{tabular}{|c|c|c|c|c|c|c|}
\hline \multicolumn{7}{|c|}{ Canada } \\
\hline & $(1)$ & $(2)$ & (3) & (4) & $(5)$ & (6) \\
\hline D.ln_gross_debt & $\begin{array}{c}0.0959 \\
(0.57)\end{array}$ & $\begin{array}{l}0.185 \\
(0.96)\end{array}$ & $\begin{array}{l}0.188 \\
(0.87)\end{array}$ & $\begin{array}{l}0.167 \\
(0.65)\end{array}$ & $\begin{array}{l}0.167 \\
(0.64)\end{array}$ & $\begin{array}{c}0.0950 \\
(0.31)\end{array}$ \\
\hline D.cpi & & $\begin{array}{c}0.00781 \\
(0.96)\end{array}$ & $\begin{array}{c}0.00754 \\
(0.88)\end{array}$ & $\begin{array}{c}0.00775 \\
(0.94)\end{array}$ & $\begin{array}{c}0.00753 \\
(0.63)\end{array}$ & $\begin{array}{c}0.00781 \\
(0.64)\end{array}$ \\
\hline LD.cpi & & & $\begin{array}{c}-0.00138 \\
(-0.17)\end{array}$ & & & \\
\hline D.ln_total_exp & & & & $\begin{array}{c}0.0375 \\
(0.11)\end{array}$ & $\begin{array}{c}0.0280 \\
(0.05)\end{array}$ & $\begin{array}{c}0.0948 \\
(0.18)\end{array}$ \\
\hline D.gdp_growth & & & & & $\begin{array}{c}-0.000208 \\
(-0.03)\end{array}$ & $\begin{array}{c}-0.000183 \\
(-0.02)\end{array}$ \\
\hline time & & & & & & $\begin{array}{c}-0.000809 \\
(-0.51)\end{array}$ \\
\hline _cons & $\begin{array}{c}0.00960 \\
(0.89)\end{array}$ & $\begin{array}{l}0.0112 \\
(1.02)\end{array}$ & $\begin{array}{l}0.0110 \\
(0.94)\end{array}$ & $\begin{array}{l}0.0115 \\
(0.99)\end{array}$ & $\begin{array}{l}0.0114 \\
(0.87)\end{array}$ & $\begin{array}{l}1.627 \\
(0.51)\end{array}$ \\
\hline $\mathrm{N}$ & 28 & 28 & 27 & 28 & 28 & 28 \\
\hline
\end{tabular}


Table 8

Robustness Regressions (Short-term Share) (Cont.)

\begin{tabular}{|c|c|c|c|c|c|c|}
\hline \multicolumn{7}{|c|}{ Germany } \\
\hline & (1) & (2) & (3) & (4) & (5) & (6) \\
\hline D.ln_gross_debt & $\begin{array}{c}-0.0525 \\
(-0.01)\end{array}$ & $\begin{array}{l}-2.992 \\
(-0.67)\end{array}$ & $\begin{array}{l}-3.289 \\
(-0.69)\end{array}$ & $\begin{array}{l}3.372 \\
(0.74)\end{array}$ & $\begin{array}{l}1.628 \\
(0.37)\end{array}$ & $\begin{array}{l}1.873 \\
(0.43)\end{array}$ \\
\hline D.cpi & & $\begin{array}{l}-0.258 \\
(-1.35)\end{array}$ & $\begin{array}{l}-0.254 \\
(-1.24)\end{array}$ & $\begin{array}{l}-0.227 \\
(-1.34)\end{array}$ & $\begin{array}{l}-0.280 \\
(-1.74)\end{array}$ & $\begin{array}{l}-0.300 \\
(-1.88)\end{array}$ \\
\hline LD.cpi & & & $\begin{array}{c}-0.00371 \\
(-0.02)\end{array}$ & & & \\
\hline D.ln_total_exp & & & & $\begin{array}{c}-11.65^{* *} \\
(-2.81)\end{array}$ & $\begin{array}{c}-14.82 * * \\
(-3.56)\end{array}$ & $\begin{array}{c}-14.81 * * \\
(-3.60)\end{array}$ \\
\hline D.gdp_growth & & & & & $\begin{array}{c}-0.178^{*} \\
(-2.11)\end{array}$ & $\begin{array}{l}-0.150 \\
(-1.75)\end{array}$ \\
\hline time & & & & & & $\begin{array}{c}0.0234 \\
(1.26)\end{array}$ \\
\hline _cons & $\begin{array}{l}0.0527 \\
(0.25)\end{array}$ & $\begin{array}{c}0.0766 \\
(0.37)\end{array}$ & $\begin{array}{l}0.0727 \\
(0.34)\end{array}$ & $\begin{array}{c}-0.0978 \\
(-0.51)\end{array}$ & $\begin{array}{c}-0.0968 \\
(-0.54)\end{array}$ & $\begin{array}{l}-46.73 \\
(-1.26)\end{array}$ \\
\hline $\mathrm{N}$ & 28 & 28 & 27 & 28 & 28 & 28 \\
\hline \multicolumn{7}{|c|}{ Italy } \\
\hline & (1) & (2) & (3) & (4) & (5) & (6) \\
\hline D.ln_gross_debt & $\begin{array}{c}-0.0283 \\
(-0.07)\end{array}$ & $\begin{array}{l}0.680 \\
(1.53)\end{array}$ & $\begin{array}{l}0.773 \\
(1.82)\end{array}$ & $\begin{array}{c}-0.0917 \\
(-0.20)\end{array}$ & $\begin{array}{l}-0.179 \\
(-0.37)\end{array}$ & $\begin{array}{l}-0.100 \\
(-0.19)\end{array}$ \\
\hline D.cpi & & $\begin{array}{c}0.0383 * * \\
(2.86)\end{array}$ & $\begin{array}{c}0.0404 * * \\
(3.09)\end{array}$ & $\begin{array}{c}0.0352 * * \\
(2.99)\end{array}$ & $\begin{array}{c}0.0364 * * \\
(3.04)\end{array}$ & $\begin{array}{c}0.0357^{* *} \\
(2.90)\end{array}$ \\
\hline LD.cpi & & & $\begin{array}{l}0.0183 \\
(1.55)\end{array}$ & & & \\
\hline D.ln_total_exp & & & & $\begin{array}{c}1.775 * * \\
(2.95)\end{array}$ & $\begin{array}{l}2.181^{*} \\
(2.71)\end{array}$ & $\begin{array}{l}2.211^{*} \\
(2.68)\end{array}$ \\
\hline D.gdp_growth & & & & & $\begin{array}{c}0.00901 \\
(0.77)\end{array}$ & $\begin{array}{l}0.0111 \\
(0.84)\end{array}$ \\
\hline time & & & & & & $\begin{array}{c}0.000868 \\
(0.37)\end{array}$ \\
\hline _cons & $\begin{array}{c}-0.0550^{*} \\
(-2.76)\end{array}$ & $\begin{array}{c}-0.0467 * \\
(-2.61)\end{array}$ & $\begin{array}{c}-0.0416^{*} \\
(-2.45)\end{array}$ & $\begin{array}{c}-0.0395^{*} \\
(-2.50)\end{array}$ & $\begin{array}{c}-0.0367^{*} \\
(-2.24)\end{array}$ & $\begin{array}{l}-1.772 \\
(-0.38)\end{array}$ \\
\hline $\mathrm{N}$ & 28 & 28 & 27 & 28 & 28 & 28 \\
\hline \multicolumn{7}{|c|}{ Japan } \\
\hline & (1) & (2) & (3) & (4) & $(5)$ & $(6)$ \\
\hline D.ln_gross_debt & $\begin{array}{c}-0.0238 \\
(-0.06)\end{array}$ & $\begin{array}{c}0.00921 \\
(0.02)\end{array}$ & $\begin{array}{l}-0.310 \\
(-0.67)\end{array}$ & $\begin{array}{c}0.0662 \\
(0.13)\end{array}$ & $\begin{array}{c}0.0624 \\
(0.12)\end{array}$ & $\begin{array}{c}0.0329 \\
(0.06)\end{array}$ \\
\hline D.cpi & & $\begin{array}{c}0.00250 \\
(0.12)\end{array}$ & $\begin{array}{c}-0.0187 \\
(-0.93)\end{array}$ & $\begin{array}{c}0.000342 \\
(0.02)\end{array}$ & $\begin{array}{c}-0.00228 \\
(-0.11)\end{array}$ & $\begin{array}{c}-0.00472 \\
(-0.21)\end{array}$ \\
\hline LD.cpi & & & $\begin{array}{c}-0.0251 \\
(-1.38)\end{array}$ & & & \\
\hline D.ln_total_exp & & & & $\begin{array}{l}-0.206 \\
(-0.35)\end{array}$ & $\begin{array}{c}0.0801 \\
(0.13)\end{array}$ & $\begin{array}{c}0.0263 \\
(0.04)\end{array}$ \\
\hline D.gdp_growth & & & & & $\begin{array}{c}0.0139 \\
(1.41)\end{array}$ & $\begin{array}{c}0.0143 \\
(1.41)\end{array}$ \\
\hline time & & & & & & $\begin{array}{c}0.000772 \\
(0.32)\end{array}$ \\
\hline _cons & $\begin{array}{c}0.0218 \\
(0.86)\end{array}$ & $\begin{array}{c}0.0208 \\
(0.77)\end{array}$ & $\begin{array}{c}0.0356 \\
(1.41)\end{array}$ & $\begin{array}{c}0.0191 \\
(0.68)\end{array}$ & $\begin{array}{c}0.0214 \\
(0.78)\end{array}$ & $\begin{array}{l}-1.518 \\
(-0.32)\end{array}$ \\
\hline $\mathrm{N}$ & 28 & 28 & 27 & 28 & 28 & 28 \\
\hline
\end{tabular}


Robustness Regressions (Short-term Share) (Cont.)

\begin{tabular}{|c|c|c|c|c|c|c|}
\hline \multicolumn{7}{|c|}{ United States } \\
\hline & $(1)$ & $(2)$ & (3) & (4) & $(5)$ & $(6)$ \\
\hline D.ln_gross_debt & $\begin{array}{l}0.0198 \\
(0.12)\end{array}$ & $\begin{array}{l}0.0938 \\
(0.47)\end{array}$ & $\begin{array}{l}0.0888 \\
(0.44)\end{array}$ & $\begin{array}{l}-0.219 \\
(-0.97)\end{array}$ & $\begin{array}{l}-0.247 \\
(-1.04)\end{array}$ & $\begin{array}{l}-0.241 \\
(-0.96)\end{array}$ \\
\hline D.cpi & & $\begin{array}{c}0.00616 \\
(0.76)\end{array}$ & $\begin{array}{l}0.0101 \\
(1.09)\end{array}$ & $\begin{array}{l}0.0130 \\
(1.62)\end{array}$ & $\begin{array}{l}0.0139 \\
(1.66)\end{array}$ & $\begin{array}{c}0.0137 \\
(1.51)\end{array}$ \\
\hline LD.cpi & & & $\begin{array}{c}0.000649 \\
(0.08)\end{array}$ & & & \\
\hline D.In_total_exp & & & & $\begin{array}{l}1.177^{*} \\
(2.37)\end{array}$ & $\begin{array}{l}1.356^{*} \\
(2.14)\end{array}$ & $\begin{array}{l}1.331 \\
(1.88)\end{array}$ \\
\hline D.gdp_growth & & & & & $\begin{array}{c}0.00265 \\
(0.47)\end{array}$ & $\begin{array}{c}0.00260 \\
(0.45)\end{array}$ \\
\hline time & & & & & & $\begin{array}{c}0.000121 \\
(0.09)\end{array}$ \\
\hline _cons & $\begin{array}{c}-0.00528 \\
(-0.47)\end{array}$ & $\begin{array}{c}-0.00497 \\
(-0.44)\end{array}$ & $\begin{array}{c}-0.00538 \\
(-0.46)\end{array}$ & $\begin{array}{c}-0.00246 \\
(-0.24)\end{array}$ & $\begin{array}{c}-0.00213 \\
(-0.20)\end{array}$ & $\begin{array}{l}-0.244 \\
(-0.09)\end{array}$ \\
\hline $\mathrm{N}$ & 28 & 28 & 27 & 28 & 28 & 28 \\
\hline
\end{tabular}

$\mathrm{t}$ statistics in parentheses

$=$ “* $\mathrm{p}<0.05 \quad{ }^{* *} \mathrm{p}<0.01 \quad{ }^{* * *} \mathrm{p}<0.001$ "

\section{CONCLUDING REMARKS AND POLICY IMPLICATIONS}

This paper investigates the impact of inflation on the public debt-to-GDP ratio in the G-7 countries. Simulations suggest that if inflation were to fall to zero for five years, the average net debt-to-GDP ratio would increase by about 5 percentage points during that period. In contrast, raising inflation to 6 percent for the next 5 years would reduce the average net debt-to-GDP ratio by about 11 percentage points under the full Fisher effect, and about 14 percentage points under the partial Fisher effect. Thus, allowing inflation to drop to very low levels for an extended period would make the task of tackling high levels of public debt even more difficult. The occasional "surprise inflation" that leaves inflation expectations unaffected could help to a degree.

However, a deliberate policy of high inflation could hardly solve the debt problem alone, and would raise significant challenges and risks. As a practical matter, lifting inflation to a meaningful level might be difficult in the current economic environment, as evidenced by Japan's experience in the last few decades, and in any case, countries in a monetary union would not be able to use this tool on their own. More importantly, reliance on inflation to erode debt could lead to fiscal dominance with inflation rates drifting even higher as confidence in the future value of money is lost. As a result, inflation expectations could be un-anchored, undermining the framework's credibility to control inflation. The un-anchoring of inflation expectations might also have significant implications for the future structure of the government debt portfolio, making it more crisis-prone by raising liquidity, currency, and the interest rate risk.

The un-anchoring of inflation expectations could increase long-term real interest rates, distort resource allocation, reduce economic growth, and hurt the lower-income households. This would likely make it difficult for governments to finance their budgets, leading to even higher debtto-GDP ratios. Introducing some form of financial repression could keep interest rates low, but such policies may be difficult to enforce in a complex financial environment, and could cause additional collateral damage to the economy. Altogether, the output costs of restoring inflation to more moderate levels in the future would be substantial - based on the experience of advanced economies in the 1980s (IMF 2012). Moreover, inflation would have a highly regressive impact on incomes: while higher inflation would be taxing on bondholders, it would also disproportionately affect lower-income households, which tend to have more limited access to indexed assets. 


\section{References}

Abbas, S.A., Akitoby, B., Andritzky, J., Berger, H., Komatsuzaki, T., and Tyson, J. (2013), "Dealing with High Debt in an Era of Low Growth," IMF Staff Discussion Note 13/7.

Aizenman, J. and N. Marion (2011), "Using Inflation to Erode the US Public Debt," Journal of Macroeconomics, 33(4): pp. 524-541.

Ball, L. (2012). The case for Four Percent Inflation. manuscript.

Blanchard, O., Dell'Ariccia, G., and Mauro, P. (2010), “Rethinking Macroeconomic Policy,” Washington, DC: International Monetary Fund

Carmichael, J. and P. Stebbing (1983), "Fisher's Paradox and the Theory of Interest," The American Economic Review, 73(4): pp. 619-630.

Cochrane, J. (2011), "Understanding Policy in the Great Recession: Some Unpleasant Fiscal Arithmetic," European Economic Review, 55(1): pp. 2-30.

Darby, M. (1975), “The Financial and Tax Effects of Monetary Policy on Interest Rates," Economic Inquiry, 13(2): pp. 266-276.

Davig, T. and E. Leeper (2011), "Monetary-Fiscal Policy Interactions and Fiscal Stimulus," European Economic Review, 55(2): pp. 211-227.

Feldstein, M. (1983), "Inflation, Income Taxes, and the Rate of Interest: A Theoretical Analysis," in Inflation, Tax Rules, and Capital Formation, Chicago, IL: University of Chicago Press.

Giannitsarou, C. and A. Scott (2008), "Inflation Implications of Rising Government Debt," in NBER International Seminar on Macroeconomics 2006, National Bureau of Economic Research, Inc., NBER Chapters, pp. $393-442$.

Hall, G. and T. Sargent (2010), "Interest Rate Risk and other Determinants of Post-WWII U.S. Government Debt/ GDP Dynamics,” NBER Working Paper No. 15702 (Cambridge, Massachusetts: National Bureau of Economic Research).

International Monetary Fund (2012). "World Economic Outlook: Coping with High Debt and Sluggish Growth," October 2012, (Washington: International Monetary Fund).

International Monetary Fund (2013), "World Economic Outlook: Hopes, Realities, and Risks," April 2013, (Washington: International Monetary Fund).

Krause, M. and S. Moyen (2011), "Public Debt and Changing Inflation Targets," Deutsche Bundesbank (Frankfurt, Germany: Deutsche Bundesbank).

Leeper, E. (1991), “Equilibria under 'Active' and 'Passive' Monetary and Fiscal Policies,” Journal of Monetary Economics, 27(1): pp. 129-147.

Missale, A. and O. Blanchard (1994), “The Debt Burden and Debt Maturity," American Economic Review, 84(1): pp. 309-319.

Mundell, R. (1963), “Inflation and Real Interest,” The Journal of Political Economy, 71(3): pp. 280-283.

Poghosyan, T. (2012), "Long-Run and Short-Run Determinants of Sovereign Bond Yields in Advanced Economies," IMF Working Paper 12/271.

Reinhart, C., K. Rogoff and M. Savastano, “Debt Intolerance," NBER Working Paper No. 9908 (Cambridge, Massachusetts: National Bureau of Economic Research)

Reinhart, C. and M. Sbrancia (2011), “The Liquidation of Government Debt,” NBER Working Paper No. 16893 (Cambridge, Massachusetts: National Bureau of Economic Research).

Rogoff, K. (2008, December 2), "Inflation is now the Lesser Evil," Project Syndicate: http://www.project-syndicate. org/commentary/inflation-is-now-the-lesser-evil

Summers, L. (1983), “The Nonadjustment of Nominal Interest Rates: A Study of the Fisher Effect,” in: J. Tobin, ed., Macroeconomic Prices and Quantities: Essays in Memory of Arthus Okun (Washington, DC: Brookings Institution).

Tobin, J. (1965), “Money and Economic Growth,” Econometrica, 33(4): pp. 671-684. 